Jurnal

Kardiologi Indonesia

J Kardiol Indones. 20I3;34:220-30

ISSN $0126 / 3773$

Clinical Research

\title{
Bleeding Predictor in ST-Elevation Myocardial Infarction Underwent Primary Percutaneous Coronary Infarction: The Indonesian (INA) Bleeding Risk Score
}

\author{
Wisnu A Widodo, Sunarya Soerianata, Andang H Joesoef, Ganesya M Harimurti
}

Departement of Cardiology and Vascular Medicine Medical Faculty Universitas Indonesia National Cardiovascular Center, Jakarta
Background Acute myocardial infarction still become one of the leading mortality cause in the world. Among these patients, ST elevation myocardial infartion (STEMI) has the greatest mortality rate among other type of Myocardial Infarction. When a myocard infarct patient have bleeding events, mortality rate greatly increased. Up until now, there is no specific bleeding risk assessment tool to predict bleeding events in STEMI patient.

Methods A retrospective cohort study, done in National Cardiovascular Center Harapan Kita, Jakarta in STEMI patients underwent Primary Percutaneous Coronary Intervention (PPCl). Bleeding event was defined according to definition by Bleeding Academic Research Consortium (BARC) - European Society of Cardiology, 20I I. Categories for data obtained was basic characteristics, clinical examinations, initial therapies, lab results, $x$-ray, $\mathrm{PPCl}$ procedures, and in hospital treatments. Statistical analysis was done using multivariat analysis using logistic regression method and then converted to a scoring system.

Results 579 sampels fit the inclusion and exclusion criteria. Bleeding event occured in 42 patients (7.3\%). Indonesia bleeding score (Range I- I 00 ) was created by assignment of variables that included in the final model according to their Odds Ratio (OR) values. Those variables are: female gender (OR 2.9I, Cl I.23-6.9I), Killip class 3 / 4 (OR 5.64, Cl 2.27-I4.03), Age $\geq$ 62 y.o (OR 2.19, Cl I.00-4.83), White blood cell > I 2.000 (OR 2.I2, Cl $0.95-4.73$ ), Creatinine > I.5 (OR 2.17, Cl 0.95-4.96), Body Mass Index $\geq$ 25 (OR I.7I, Cl 0.83-3.5I), Multiple coronary lesion (OR I.95, Cl 0.834.54), Femoral access (OR 2.33, Cl 0.77-7.0 I), and TPM implantation (OR 3.2 I, Cl I.28-8.07). These variabels was converted into two type of scoring system. The INA-I contains all of the variables, and INA-2 minus variables related to interventional result and procedures.

Conclusion Indonesia bleeding score quantifies risk for in-hospital bleeding event in STEMI patients underwent PPCl, which enhances baseline risk assessment for STEMI care.

(J Kardiol Indones. 20 I3;34:220-30)

Keywords: Myocardial infarction, STEMI, primary PCI, bleeding, predictor, risk evaluation 


\title{
Sistem Skor Baru untuk Memprediksi Kejadian Perdarahan pada Pasien Infark Miokard Akut dengan Elevasi Segmen ST yang Dilakukan Intervensi Koroner Perkutan Primer
}

\author{
Wisnu A Widodo, Sunarya Soerianata, Andang H Joesoef, Ganesya M Harimurti
}

\begin{abstract}
Latar Belakang. Kejadian perdarahan pada pasien Infark Miokard Akut (IMA) berkaitan dengan peningkatan mortalitas secara signifikan. Angka kejadian perdarahan ditemukan lebih tinggi pada populasi Infark Miokard Akut dengan Elevasi Segmen ST (IMA-EST) dibandingkan tipe lainnya. Hingga saat tulisan ini dibuat, belum ada satupun sistem skor yang dibuat khusus untuk populasi IMA-EST.

Metodologi. Studi retrospektif kohort yang dilakukan di Pusat Jantung Nasional Harapan Kita, Jakarta pada pasien IMA-EST yang menjalani intervensi koroner perkutan primer (IKPP). Kejadian perdarahan menggunakan definisi Bleeding Academic Research Consortium (BARC). Total 48 variabel dikumpulkan dan diuji. Data kemudian diolah dengan analisis multivariat menggunakan metode logistik regresi dan diubah menjadi suatu sistem skor.

Hasil. Sebanyak 579 sampel berhasil dikumpulkan, dengan 42 diantaranya mengalami perdarahan (7.3\%). Variabel yang masuk ke dalam model akhir adalah: Jenis kelamin perempuan, kelas Killip 3 / 4, Umur $\geq 62$ tahun, Leukosit $>12.000$, Kreatinin $>1.5$, IMT $\geq 25$, Lesi koroner multipel, Akses femoral, dan Pemasangan TPM. Uji diskriminasi dan kalibrasi dari model akhir menunjukkan hasil baik. Model alternatif dibuat dengan menghilangkan variabel yang berkaitan dengan hasil dan prosedur tindakan intervensif sehingga dapat digunakan untuk stratifikasi awal pre-IKPP.

Kesimpulan. Sistem skor baru merupakan suatu sistem prediksi kejadian perdarahan pada populasi khusus IMA-EST yang menjalani IKPP. Skor ini memiliki nilai kalibrasi dan diskriminasi yang baik sehingga diharapkan dapat membantu manajemen pasien IMA-EST.
\end{abstract}

(J Kardiol Indones. 2013;34:220-30)

Kata Kunci: Infark miokard, IMA-EST, IKPP, kejadian perdarahan, prediktor, evaluasi risiko

\section{Alamat Korespondensi}

dr. Wisnu A Widodo, SpJP. Departemen Kardiologi dan Kedokteran Vaskular FKUI, dan Pusat Jantung Nasional Harapan Kita, Jakarta. E-mail: wishnu.aditya@gmail.com

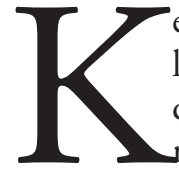
emajuan pesat dalam peningkatkan tatalaksana pasien sindrom koroner akut (IMA) dengan terapi antitrombotik dan tindakan evaskularisasi telah berperan pada penurunan angka morbiditas dan mortalitas pada penyakit ini. ${ }^{1}$ Strategi tatalaksana ini menyebabkan semakin banyaknya 
komplikasi terkait pemberian obat antitrombotik dan tindakan intervensif, salah satu yang paling kerap muncul adalah kejadian perdarahan. Hasil analisa register IMA dalam skala besar secara konsisten menunjukkan bahwa pasien IMA yang mengalami kejadian perdarahan memiliki tingkat morbiditas dan mortalitas yang lebih tinggi secara signifikan. ${ }^{2,3}$

Saat ini telah terdapat beberapa sistem skor yang untuk memprediksi kejadian perdarahan pada pasien IMA, yaitu Skor perdarahan CRUSADE untuk pasien IMA tanpa elevasi segmen ST dan sistem skor dari data studi ACUITY-HORIZONS yang melibatkan pasien IMA dengan dan tanpa elevasi segmen ST. Hingga saat tulisan ini dibuat, belum ada sistem skor untuk memprediksi kejadian perdarahan pada pasien IMA-EST. ${ }^{4,5}$

\section{Metodologi Penelitian}

\section{Populasi}

Penelitian ini merupakan studi kohort retrospektif yang melibatkan pasien IMA-EST yang dilakukan tindakan IKPP. Subjek yang termasuk dalam populasi sampel adalah pasien Pusat Jantung Nasional Harapan Kita (PJNHK) yang terdiagnosa sebagai IMA-EST dengan onset kurang dari 12 jam, menjalani IKPP, dan tidak dilakukan tindakan fibrinolitik sebelumnya. Pasien yang menjalani operasi CABG selama perawatan tidak dimasukkan sebagai subjek.

\section{Definisi Operasional}

Perdarahan didefinisikan sebagai kejadian klinis perdarahan disertai penurunan hemoglobin $3 \mathrm{~g} / \mathrm{dL}$ atau lebih, dan atau dilakukan transfusi darah karena kejadian perdarahan. Definisi ini digunakan mengikuti definisi perdarahan tipe 3 dari Bleeding Academirc Research Consortium (BARC) yang dipublikasi oleh European Society of Cardiology tahun 2011.6 Tidak termasuk dalam kategori perdarahan pada penelitian ini: perdarahan yang terjadi selama atau setalah tindakan operasi. Intervensi koroner perkutan primer didefinisikan sebagai tindakan intervensi koroner yang dilakukan pada pasien IMA-EST dengan onset kurang dari 12 jam. Nilai Indeks massa tubuh (IMT) dihitung dengan rumus berat badan (dalam kilogram) dibagi dengan pangkat dua dari tinggi badan (dalam meter). Henti jantung didefinisikan sebagai kejadian ventrikular takikardi tanpa nadi atau ventrikular fibrilasi mulai dari onset nyeri dada hingga selesai tindakan intervensi perkutan.

\section{Karakteristik dasar}

Sebanyak 579 sampel berhasil dikumpulkan, dengan 42 diantaranya mengalami perdarahan (7.3\%). Nilai median umur pasien pada penelitian ini adalah 55 tahun dengan mayoritas berjenis kelamin laki-laki (86\%). Diabetes dialami oleh $41.3 \%$ pasien, dan hipertensi oleh $57.7 \%$ pasien. Nilai median onset IMA-EST adalah 5.5 jam dengan gambaran klinis kelas Killip 1. Loading Gp2b3a sebelum tindakan diberikan pada $73.1 \%$ pasien. $90.2 \%$ pasien dipasang stent pada prosedur IKPP, dan $70.3 \%$ dari seluruh tindakan menggunakan akses femoral. Hasil angiografi menunjukkan $60.8 \%$ pasien memiliki lebih dari satu lesi koroner (multivessel disease). TPM dipasang pada 6.9\% dari keseluruhan pasien, dan selama perawatan maintenance heparin diberikan pada $41.3 \%$ pasien. (Tabel 1).

\section{Hasil}

\section{Analisis Statistik}

Uji statistik dilakukan dengan melakukan komparasi proporsi dari data yang telah dikumpulkan. Data kontinyu ditampilkan sebagai median dan nilai persentil $(25,75)$. Sedangkan data kategorik ditampilkan sebagai persentase. Selanjutnya dilakukan analisis bivariat antar variabel-variabel prediktor dengan kejadian perdarahan. Nilai Odds Ratio (OR) dan interval kepercayaan menjadi pertimbangan dalam penentuan faktor akan masuknya faktor ke dalam model. Variabel yang memiliki interval kepercayaan minimum mendekati 1 dan cenderung positif dimasukkan ke dalam analisis multivariat. Variabel umum utama yang diperkirakan berhubungan dengan kejadian perdarahan (berdasarkan penelitian sebelumnya) dimasukkan terlebih dahulu, kemudian selanjutnya berurutan sesuai kerangka konsep yang sudah dibuat. Variabel yang saling berinteraksi atau tidak memberikan perubahan signifikan akan disingkirkan dari model. Hal ini dilakukan hingga mendapatkan model yang memberikan rasio likelihood yang paling baik (Maximum likelihood). Setelah melakukan 
analisis multivariat, didapatkan model akhir yang mempunyai likelihood paling baik, dan model alternatif yang menghilangkan variabel hasil dan tindakan intervensi perkutan sehingga dapat diterapkan pada pusat pelayanan kesehatan yang tidak memiliki fasilitas intervensi koroner.

\section{Model akhir (MODEL-I) dan model alternatif (MODEL-2)}

Variabel yang masuk ke dalam model akhir (MODEL-1) adalah jenis kelamin perempuan (OR 2.91, CI 1.236.91), kelas Killip 3 / 4 (OR 5.64, CI 2.27-14.03),

Tabel 1. Karakteristik dasar berdasarkan kejadian perdarahan

\begin{tabular}{|c|c|c|c|}
\hline Variabel & $\begin{array}{c}\text { Seluruh sampel } \\
\mathrm{n}=579\end{array}$ & $\begin{array}{c}\text { Tidak perdarahan } \\
\mathrm{n}=537(92.7 \%)\end{array}$ & $\begin{array}{c}\text { Perdarahan } \\
\mathrm{n}=42(7.3 \%)\end{array}$ \\
\hline \multicolumn{4}{|l|}{ Karakteristik dasar } \\
\hline Usia, tahun & $55.0(50.0,61.0)$ & $55.0(50.0,61.0)$ & $58.5(53.0,69.0)$ \\
\hline Jenis kelamin perempuan, $\%$ & 14.0 & 12.9 & 28.6 \\
\hline IMT, $\mathrm{kg} / \mathrm{m}^{2}$ & $24.5(22.9,26.9)$ & $24.4(22.7,26.9)$ & $25.3(23.4,27.1)$ \\
\hline Diabetes, \% & 41.3 & 42.3 & 31.0 \\
\hline Hipertensi, \% & 57.7 & 57.6 & 57.1 \\
\hline Dislipidemia, \% & 85.0 & 84.9 & 85.7 \\
\hline Riwayat stroke, \% & 6.0 & 5.7 & 9.5 \\
\hline Riwayat gastritis, $\%$ & 18.8 & 18.3 & 28.6 \\
\hline \multicolumn{4}{|l|}{ Pemeriksaan awal } \\
\hline Tekanan darah Sistolik, mmHg & $130.0(113.0,148.0)$ & $130.0(114.0,149.0)$ & $117.0(94.0,134.0)$ \\
\hline Frekuensi nadi, /menit & $75.0(64.0,91.0)$ & $75.0(64.0,91.0)$ & $81.5(62.0,103.0)$ \\
\hline CTR $>58 \%, \%$ & 13.1 & 12.5 & 14.3 \\
\hline Hemoglobin & $14.5(13.4,15.5)$ & $14.5(13.4,15.5)$ & $14.5(13.3,15.4)$ \\
\hline Leukosit, /mcL & $12510(10400,15080)$ & $12320(10325,14910)$ & $14340(12692,16285)$ \\
\hline Kreatinin, mg/dL & $1.0(0.9,1.3)$ & $1.0(0.85,1.29)$ & $1.3(0.95,1.72)$ \\
\hline Gula darah sewaktu, mg/dL & $149.0(125.0,211.0)$ & $148.0(125.0,211.0)$ & $155.0(129.0,234.0)$ \\
\hline Onset STEMI & $5.5(4.0,7.5)$ & $5.5(4.0,7.5)$ & $5(3.9,7.0)$ \\
\hline Skor TIMI & $4.0(3.0,5.0)$ & $4.0(3.0,5.0)$ & $5.0(3.0,7.0)$ \\
\hline Kelas KILLIP 1 dan 2, \% & 93.4 & 95.0 & 69.0 \\
\hline Kelas KILLIP 3 dan 4, \% & 6.6 & 5.0 & 31.0 \\
\hline Henti jantung, \% & 4.0 & 3.5 & 19.5 \\
\hline \multicolumn{4}{|l|}{ Terapi awal } \\
\hline Loading Aspilet, \% & 97.8 & 98.0 & 95.2 \\
\hline Loading Clopidogrel, \% & 96.7 & 96.7 & 97.6 \\
\hline Loading Ticagrelor, \% & 1.6 & 1.5 & 2.4 \\
\hline Loading Gp2b3a sebelum IKPP, \% & 73.1 & 72.3 & 85.7 \\
\hline \multicolumn{4}{|l|}{ Prosedur IKPP } \\
\hline Dipasang stent, \% & 90.2 & 90.8 & 81.0 \\
\hline Total bolus heparin, IU & $6000(5000-7000)$ & $6000(5000,7000)$ & $5500(5000,7000)$ \\
\hline Multivessel disease, $\%$ & 60.8 & 60.1 & 78.6 \\
\hline Akses femoral, \% & 70.3 & 69.2 & 88.1 \\
\hline Pindah puncture site, $\%$ & 11.1 & 11.4 & 7.1 \\
\hline Gp2b3a Intrakoroner, \% & 9.2 & 8.7 & 14.3 \\
\hline Pemasangan TPM, \% & 6.9 & 5.5 & 26.2 \\
\hline \multicolumn{4}{|l|}{ Selama perawatan } \\
\hline Diberikan maintenance Heparin, \% & 41.3 & 40.0 & 61.9 \\
\hline Meninggal, \% & 1.6 & 0.6 & 14.3 \\
\hline
\end{tabular}


Jurnal Kardiologi Indonesia

Tabel 2. Hasil analisis bivariat

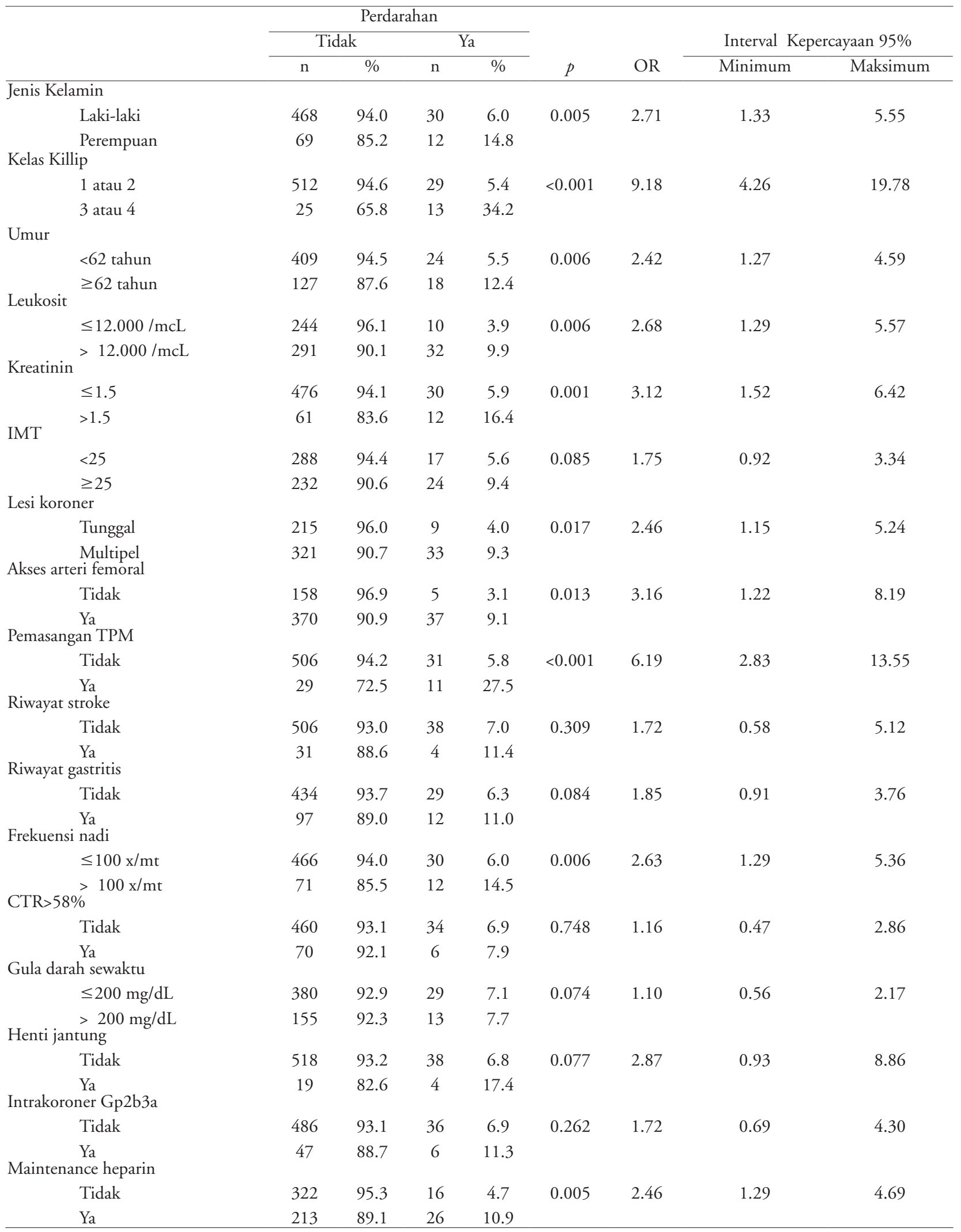


Umur $\geq 62$ tahun (OR 2.19, CI 1.00-4.83), Leukosit $>12.000$ (OR 2.12, CI 0.95-4.73), Kreatinin >1.5 (OR 2.17, CI 0.95-4.96), IMT $\geq 25$ (OR 1.71, CI 0.83-3.51), Lesi koroner multipel (OR 1.95, CI 0.834.54), Akses femoral (OR 2.33, CI 0.77-7.01), dan Pemasangan TPM (OR 3.21, CI 1.28-8.07). Pada model alternatif (MODEL-2), parameter intervensi koroner (Lesi koroner multipel, akses femoral, dan pemasangan TPM) dihilangkan. Uji kalibrasi yang dilakukan dengan metode Hosmer dan Lomeshow pada kedua model menunjukkan bahwa model terkalibrasi dengan baik (nilai $\mathrm{p}>0.05$ ). Begitupun juga uji diskriminasi yang dilakukan dengan analisa Receiver Operating Characteristic (ROC) menunjukkan nilai AUC lebih dari 0.8 (kemampuan diskriminasi kuat).

Pembobotan setiap variabel didasarkan pada nilai odds ratio dengan skor maksimum 100. Setelah dilakukan pembulatan dan pembobotan pada setiap variabel didapatkan sistem skor seperti yang tertera pada tabel 4.

Dari hasil analisis logistik regresi sistem skor didapatkan persamaan regresi untuk masing-masing model. Untuk model akhir (MODEL-1) $y=-5.318$ $+(0.080 \mathrm{x}$ total skor $)$, dan untuk model alternatif

Tabel 3. Model akhir (MODEL-1) dan model alternatif (MODEL-2)

\begin{tabular}{|c|c|c|c|c|}
\hline \multirow{2}{*}{ Model akhir (MODEL-1) } & \multirow{2}{*}{ Odds Ratio } & \multirow{2}{*}{ Nilai P } & \multicolumn{2}{|c|}{ Interval Kepercayaan 95\% } \\
\hline & & & Minimum & Maksimum \\
\hline Jenis kelamin perempuan & 2.91 & 0.015 & 1.23 & 6.91 \\
\hline Killip 3/4 & 5.64 & 0.000 & 2.27 & 14.03 \\
\hline Umur $\geq 62$ tahun & 2.19 & 0.051 & 1.00 & 4.83 \\
\hline Leukosit $>12.000$ & 2.12 & 0.066 & 0.95 & 4.73 \\
\hline Kreatinin $>1.5$ & 2.17 & 0.067 & 0.95 & 4.96 \\
\hline $\mathrm{IMT} \geq 25$ & 1.71 & 0.147 & 0.83 & 3.51 \\
\hline Lesi koroner multipel & 1.95 & 0.123 & 0.83 & 4.54 \\
\hline Akses femoral & 2.33 & 0.132 & 0.77 & 7.01 \\
\hline Dipasang TPM & 3.21 & 0.013 & 1.28 & 8.07 \\
\hline \multirow{2}{*}{ Model alternatif (MODEL-2) } & \multirow{2}{*}{ Odds Ratio } & \multirow{2}{*}{ Nilai P } & \multicolumn{2}{|c|}{ Interval Kepercayaan 95\% } \\
\hline & & & Minimum & Maksimum \\
\hline Jenis kelamin perempuan & 2.87 & 0.013 & 1.25 & 6.58 \\
\hline Killip 3 / 4 & 7.74 & 0.000 & 3.24 & 18.49 \\
\hline Umur $\geq 62$ tahun & 2.60 & 0.013 & 1.22 & 5.55 \\
\hline Leukosit $>12.000$ & 2.34 & 0.033 & 1.07 & 5.11 \\
\hline Kreatinin $>1.5$ & 2.51 & 0.025 & 1.12 & 5.60 \\
\hline IMT $\geq 25$ & 1.96 & 0.060 & 0.97 & 3.96 \\
\hline
\end{tabular}

Tabel 4. Skor untuk model akhir (MODEL-1) dan model alternatif (MODEL-2)

\begin{tabular}{|c|c|c|c|}
\hline Variabel & Skor & & \\
\hline Jenis Kelamin Perempuan & 12 & & \\
\hline Umur $\geq 62$ tahun & 8 & & \\
\hline $\mathrm{IMT} \geq 25$ & 8 & Variabel & Skor \\
\hline Kelas Killip 3 atau 4 & 25 & Jenis Kelamin Perempuan & 14 \\
\hline Jumlah leukosit $>12.000$ & 8 & Umur $\geq 62$ tahun & 12 \\
\hline Nilai kreatinin > 1.5 & 8 & $\mathrm{IMT} \geq 25$ & 10 \\
\hline Akses Femoral & 10 & Kelas Killip 3 atau 4 & 40 \\
\hline Lesi koroner Multipel & 8 & Jumlah leukosit $>12.000$ & 12 \\
\hline Pemasangan TPM & 13 & Nilai kreatinin $>1.5$ & 12 \\
\hline TOTAL & 100 & TOTAL & 100 \\
\hline
\end{tabular}


Jurnal Kardiologi Indonesia

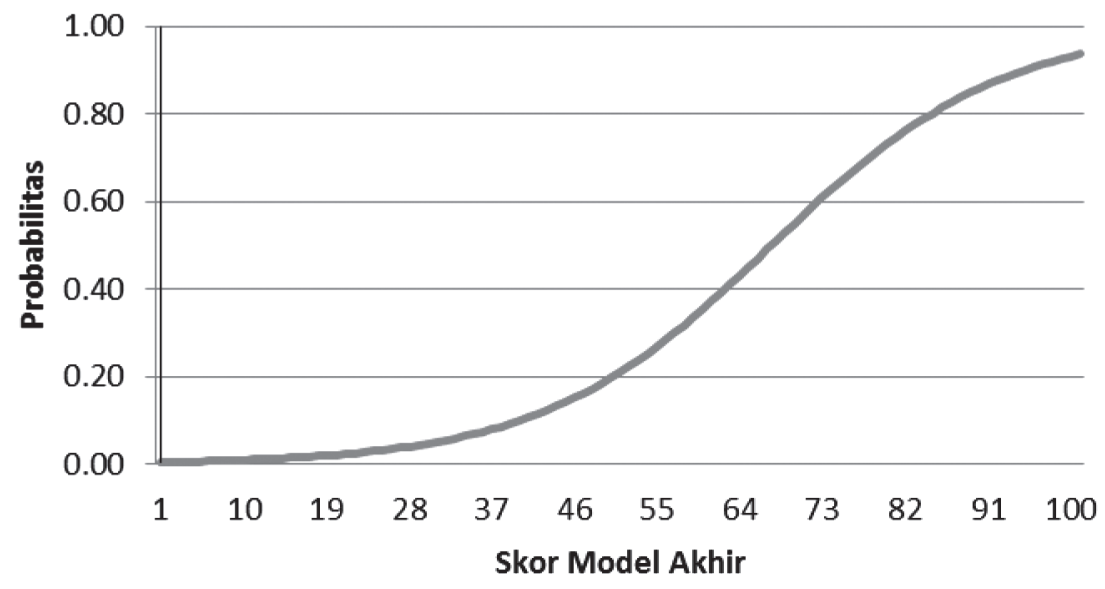

Gambar 1. Grafik probabilitas model akhir (MODEL-1)

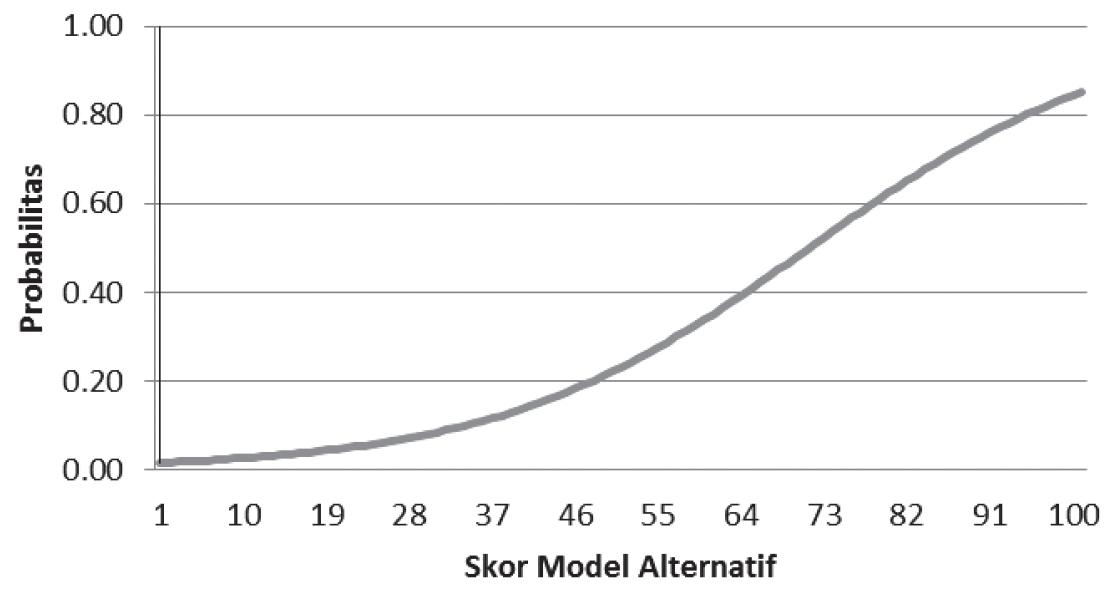

Gambar 2. Grafik probabilitas model alternatif (MODEL-2)

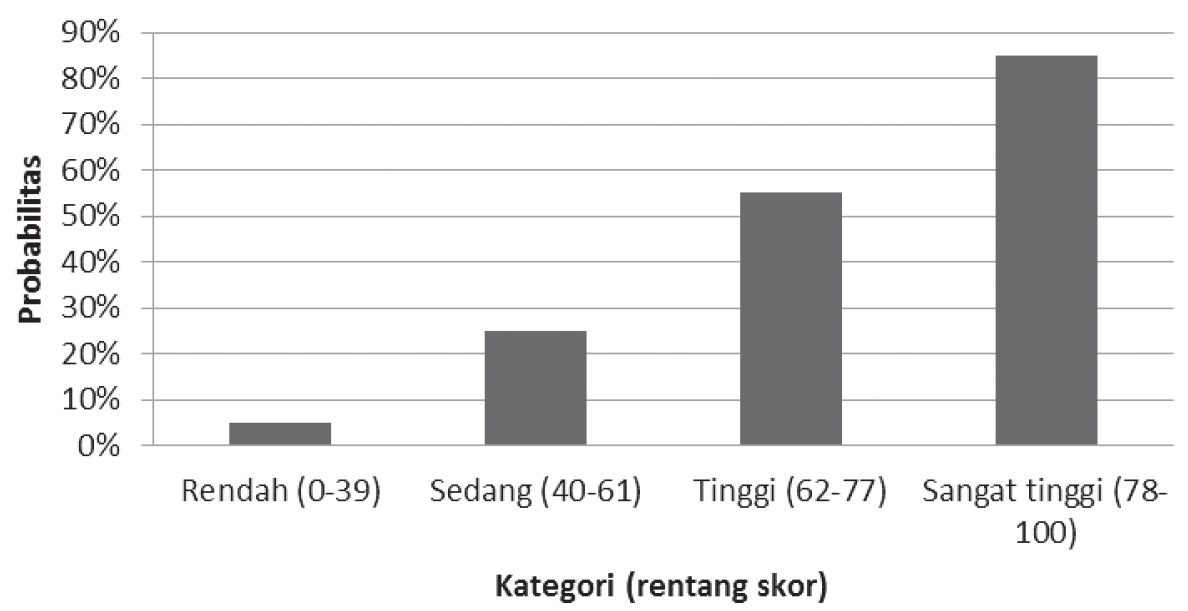

Gambar 3. Kategori skor dan probabilitas dari model akhir (MODEL-1) 
Widodo WA dkk: Skor prediksi perdarahan IMA-EST yang menjalani IKP primer

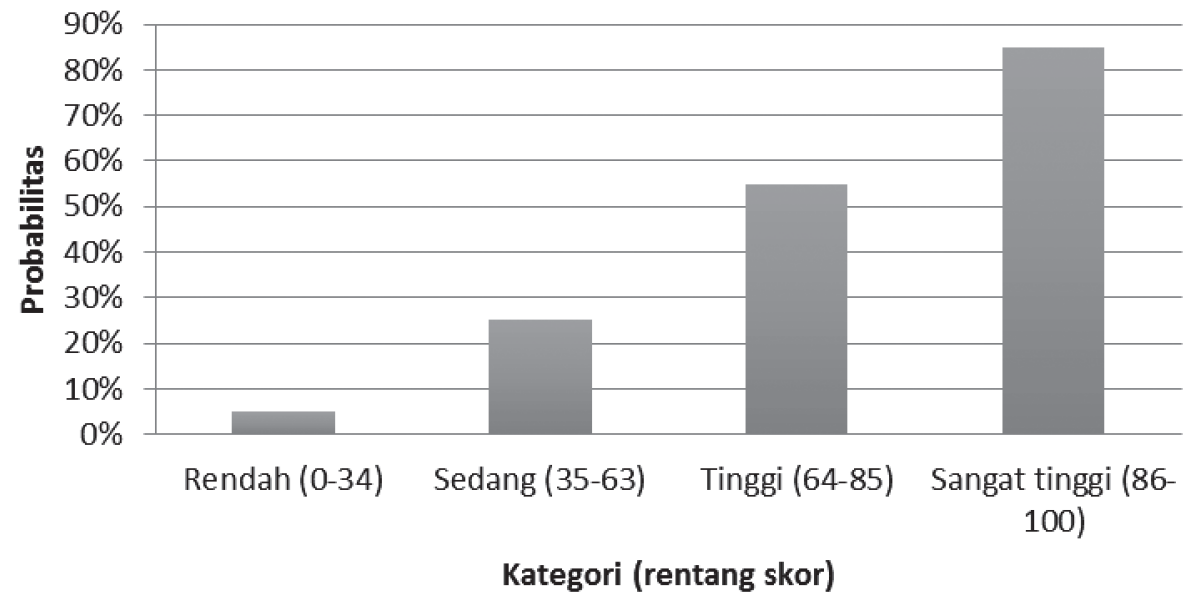

Gambar 4. Kategori skor dan probabilitas dari model alternatif (MODEL-2)

(MODEL-2) $y=-4.152+(0.059 \mathrm{x}$ total skor $)$. Nilai probabilitas dihitung dengan menggunaan persamaan $p=1 /(1+\exp (-y))$. Selanjutnya nilai probabilitas ini diplot ke dalam grafik probabilitas-skor (gambar 1 dan 2).

Selanjutnya dibuat kategori dari skor untuk memudahkan interpretasi klinis. Nilai skor MODEL-1 0-39 memiliki probabilitas 0-10\% dan dikategorikan sebagai kategori rendah, skor 40-61 memiliki probabilitas $11-40 \%$ disebut sebagai kategori sedang,skor $62-77$ memiliki probabilitas $41-70 \%$ disebut sebagai kategori tinggi, dan skor 78-100 memiliki probabilitas 71-94\% disebut sebagai kategori sangat tinggi. Sedangkan pembagian untuk model alternatif MODEL-2 adalah 0-34 dikategorikan sebagai kategori rendah, skor 35-63 sebagai kategori sedang, skor 64-85 sebagai kategori tinggi, dan skor 78-100 sebagai kategori sangat tinggi.

\section{Pembahasan}

Dari hasil pengambilan data retrospektif 579 pasien, kami mengidentifikasi 9 faktor yang berkaitan dengan kejadian perdarahan pada pasien IMA-EST yang dilakukan IKPP, yaitu: Jenis kelamin perempuan,

Tabel 5 Perbandingan komponen dan nilai AUC dari skor baru dan pendahulu

\begin{tabular}{|c|c|c|c|c|}
\hline & CRUSADE (2009) & ACUITY-HORIZONS (2010) & ACTION-GWTG (2011) & Sistem Skor Baru (2013) \\
\hline \multirow[t]{2}{*}{ Tipe SKA } & IMA-NSTE & IMA-NSTE & IMA-NSTE & IMA-EST \\
\hline & & IMA-EST & IMA-EST & \\
\hline \multirow[t]{12}{*}{ Variabel model } & Perempuan & Perempuan & Perempuan & Perempuan \\
\hline & Diabetes & Umur & Umur & Umur \\
\hline & Bersihan kreatinin & Kreatinin & Berat badan & IMT \\
\hline & Penyakit vaskular & Leukosit & Penggunaan warfarin & Kelas Killip \\
\hline & Hematokrit $<36 \%$ & Anemia & Diabetes & Kreatinin \\
\hline & Gagal jantung & Presentasi klinis & Penyakit vaskular & Leukosit \\
\hline & Frekuensi nadi & Antitrombotik & Hemoglobin & Akses femoral \\
\hline & Sistolik $<110 \mathrm{mmHg}$ & & Kreatinin & Lesi koroner multipel \\
\hline & Diastolik > $180 \mathrm{mmHg}$ & & Gagal jantung / syok & TPM \\
\hline & & & Frekuensi nadi & \\
\hline & & & Tekanan darah sistolik & \\
\hline & & & Perubahan EKG & \\
\hline$C$-statistic & 0.71 & 0.74 & 0.73 & 0.84 \\
\hline
\end{tabular}


umur $\geq 62$ tahun, IMT $\geq 25$, kelas Killip 3/4, jumlah leukosit $>12.000$, nilai kreatinin $>1.5$, lesi koroner multipel, akses femoral, dan pemasangan TPM. Faktor-faktor ini terdiri dari kategori klinis, laboratoris, dan tindakan intervensif. Sejalan dengan penemuan ini, teori yang banyak dianut juga menyatakan bahwa kejadian perdarahan dipengaruhi berbagai macam faktor (multifaktorial). ${ }^{3,4,5}$

Faktor-faktor kategori klinis dan laboratoris yang berhasil teridentifikasi pada penelitian ini konsisten dengan yang ditemukan dari penelitian-penelitian pendahulu. Jenis kelamin, umur, berat badan, tanda gagal jantung, nilai leukosit, dan bersihan kreatinin juga telah diidentifikasi oleh Moscucci (2003), Subherwal (2009), dan Mehran (2011).3,4,7 Hal yang baru pada penelitian ini adalah dimasukkannya variabel hasil dan tindakan intervensi perkutan.

Hal yang unik mengenai sistem skor ini adalah diperhitungkannya faktor-faktor yang berhubungan dengan prosedur intervensi perkutan. Hasil penelitian ini menunjukkan bahwa akses femoral, pemasangan TPM, dan hasil angiografi merupakan faktor yang perlu diperhitungkan. Akses femoral dan pemasangan TPM memiliki bobot yang cukup tinggi, dan hal ini memperlihatkan bahwa cedera iatrogenik pada pembuluh arteri berkaitan dengan meningkatkan kejadian perdarahan. Hal ini sejalan dengan yang dikemukakan oleh Barthelemy (2010) dan Klutstein (2013) bahwa pemilihan akses femoral berkaitan dengan angka kejadian perdarahan yang lebih tinggi pada pasien IMA-EST yang dilakukan IKPP. ${ }^{8,9}$

Salah satu kesulitan dalam komparasi kejadian perdarahan antar studi adalah tidak seragamnya definisi perdarahan yang digunakan pada berbagai studi. Untuk menjembatani hal ini, pada tahun 2011 European Society of Cardiology melalui Bleeding Academic Research Consortium membuat definisi perdarahan BARC yang diformulasikan menggunakan komponen penilaian klinis, laboratoris, dan pemberian transfusi. ${ }^{6}$ Di masa depan, diharapkan semua studi SKA menerapkan definisi perdarahan ini, sehingga definisi perdarahan menjadi seragam pada semua studi SKA. Sejauh pengetahuan penulis, hingga saat ini belum ada sistem prediksi yang menggunakan definisi tersebut, sehingga kami mencoba mengembangkan sistem prediksi dengan menggunakan definisi perdarahan BARC.

Dalam seleksi sampel, dilakukan eksklusi pada pasien IMA-EST yang telah atau memiliki riwayat dilakukan fibrinolitik. Hal ini dilakukan karena terapi tersebut sudah terbukti sangat meningkatkan kejadian perdarahan, dan strategi penatalaksanaan pasien yang mendapat terapi tersebut pun berbeda. ${ }^{10,11}$

Selanjutnya kami mengembangkan sistem prediksi dari faktor-faktor yang telah teridentifikasi tersebut untuk aplikasi klinis dengan menggunakan metodek skor. Hal ini dilakukan karena sejauh pengetahuan penulis dan hingga saat tulisan ini dibuat, sistem prediksi perdarahan yang telah dikembangkan untuk SKA belum ada yang mewakili populasi IMA-EST secara khusus, sehingga masih ada keraguan dalam penerapan klinisnya. ${ }^{12}$ Sistem skor CRUSADE dibuat untuk populasi IMA-NEST, sedangkan sistem skor ACUITY-HORIZONS dan sistem skor ACTION dibuat untuk populasi IMANEST dan IMA-EST. ${ }^{4,5}$

Analisa C-Statistic dari sistem skor baru yang dikembangkan memberikan hasil yang baik saat diaplikasikan pada populasi aslinya. Nilai AUC 0.84 menunjukkan sistem memiliki nilai kalibrasi yang baik, bahkan secara teoritis lebih baik dari sistem prediksi kejadian perdarahan sebelumnya yang memiliki nilai AUC maksimal 0.74 (tabel 5). ${ }^{12}$ Namun hal ini masih harus dibuktikan kembali saat dilakukan validasi.

Jika melihat nilai pembobotan tiap komponen (yang didasarkan oleh nilai OR) pada sistem skor baru ini, pembobotan tertinggi ada pada variabel kelas Killip. Kesimpulan yang bisa diambil dari hal ini adalah semakin berat dampak klinis (insult) yang dialami pasien, semakin tinggi kemungkinan terjadinya perdarahan. Di sisi lain, Rao (2006) mengungkapkan hal senada dari sisi yang berbeda, bahwa perdarahan akan memiliki dampak klinis yang besar, sehingga kemungkinan kedua aspek ini memang saling mempengaruhi dan berinteraksi kuat. ${ }^{13}$

Analisis subgrup menunjukkan bahwa pasien yang mengalami perdarahan memiliki proporsi terapi maintenance heparin yang lebih tinggi (40.0\% grup non perdarahan vs $61.9 \%$ perdarahan), dan sebagian besar diantaranya menggunakan jenis UFH (6.1\% non perdarahan vs. $33.3 \%$ perdarahan). Hal ini sejalan dengan kesimpulan dari penelitian besar FINESSE, ATOLL, dan OASIS 5 bahwa pemberian heparin jenis Low-Molecular Weight berkaitan dengan kejadian perdarahan yang lebih rendah. ${ }^{14}$ Pemberian antiplatelet Gp2b3a lanjutan juga menunjukkan kecenderungan terhadap terjadinya perdarahan $(7.7 \%$ non perdarahan $v s .14 .3 \%$ perdarahan), sejalan dengan yang disampaikan oleh Giugliano (2009). ${ }^{15}$ Namun faktor ini tidak dapat dimasukkan ke dalam model 
akhir, karena pemberian UFH berinteraksi kuat dengan kelas Killip dan nilai kreatinin.

Patofisiologi kejadian perdarahan pada pasien SKA merupakan hal yang belum banyak dipelajari. Hingga tulisan ini dibuat, belum pernah dilakukan suatu penelitian khusus untuk menjawab pertanyaan bagaimana mekanisme komponen-komponen yang sudah teridentifikasi menimbulkan kejadian perdarahan, dan tampaknya penyebabnya multifaktorial. ${ }^{16,17,18}$

Pengembangan model sistem prediksi kami lakukan untuk mempermudah aplikasi klinis. Dua model sistem skor dibuat melalui langkah-langkah statistik yang sudah dijelaskan pada bagian hasil. Sistem skor model 1 merupakan sistem skor yang memiliki komponen penilaian klinis, laboratoris, dan intervensif, sehingga idealnya diterapkan pada ruang perawatan intensif setelah dilakukan tindakan IKPP. Model 2 menghapus komponen intervensif, sehingga dapat digunakan untuk stratifikasi awal sebelum tindakan IKPP. Kedua metode ini memiliki nilai kalibrasi yang baik (AUC >0.8).

\section{Kesimpulan}

Skor perdarahan baru (MODEL-1) tersusun dari 9 komponen klinis, laboratoris, dan tindakan intervensif yang digabungkan menjadi satu sistem skor dan dapat memprediksi kejadian perdarahan pada pasien IMAEST. Sedangkan skor perdarahan baru alternatif (MODEL-2) menghilangkan komponen hasil dan prosedur invasif sehingga dapat diterapkan pada pusat pelayanan kesehatan tanpa fasilitas intervensi kardiak. Diharapkan sistem skor ini mampu membantu tatalaksana pasien IMA-EST dan mengurangi angka kejadian perdarahan.

\section{Daftar Pustaka}

1. Stone GW, Ware JH, Bertrand ME, et al. Antithrombotic strategies in patients with acute coronary syndromes undergoing early invasive management: one-year results from the ACUITY trial. JAMA 2007;298:2497-506.

2. Gitt AK, Towae F, Zahn R, et al. Major Bleeding Complications in Patients with Stemi Account for a Doubling in Hospital Mortality in Clinical Practice: Lessons from the Euro Heart Survey ACS Registry. Journal of the American College of Cardiology 2010;55:A101.E945-A101.E945.

3. Moscucci M. Predictors of major bleeding in acute coronary syndromes: the Global Registry of Acute Coronary Events (GRACE). European Heart Journal 2003;24:1815-23.

4. Subherwal S, Bach RG, Chen AY, et al. Baseline Risk of Major Bleeding in Non-ST-Segment-Elevation Myocardial Infarction: The CRUSADE (Can Rapid risk stratification of Unstable angina patients Suppress ADverse outcomes with Early implementation of the ACC/AHA guidelines) Bleeding Score. Circulation 2009;119:1873-82.

5. Mathews R, Peterson ED, Chen AY, et al. In-hospital major bleeding during ST-elevation and non-ST-elevation myocardial infarction care: derivation and validation of a model from the ACTION Registry(R)-GWTG. Am J Cardiol 2011;107:113643.

6. Steg PG, Huber K, Andreotti F, et al. Bleeding in acute coronary syndromes and percutaneous coronary interventions: position paper by the Working Group on Thrombosis of the European Society of Cardiology. European Heart Journal 2011;32:185464.

7. Mehran R, Pocock SJ, Nikolsky E, et al. A Risk Score to Predict Bleeding in Patients With Acute Coronary Syndromes. Journal of the American College of Cardiology 2010;55:2556-66.

8. Barthelemy O JS, Anne Bellemain-Appaix, F. Beygui, J.P. Collet. Incidence, type and prognostic impact of bleeding complications with radial primary PCI of STEMI: The Pitié-Salpêtrière experience. Archives of Cardiovascular Diseases Supplements 2010;2:6.

9. Klutstein MW, Westerhout CM, Armstrong PW, et al. Radial versus femoral access, bleeding and ischemic events in patients with non-ST-segment elevation acute coronary syndrome managed with an invasive strategy. Am Heart J 2013;165:583-90 e1.

10. Steinhubl SR, Kastrati A, Berger PB. Variation in the definitions of bleeding in clinical trials of patients with acute coronary syndromes and undergoing percutaneous coronary interventions and its impact on the apparent safety of antithrombotic drugs. Am Heart J 2007;154:3-11.

11. Verheugt FW, Steinhubl SR, Hamon M, et al. Incidence, prognostic impact, and influence of antithrombotic therapy on access and nonaccess site bleeding in percutaneous coronary intervention. JACC Cardiovasc Interv 2011;4:191-7.

12. X Flores-Ríos DC-M, J Rodríguez-Garrido, M GarcíaGuimaraes, P Gargallo-Fernández, P Piñón-Esteban. Comparison of the performance of the CRUSADE, ACUITYHORIZONS, and ACTION bleeding risk scores in STEMI undergoing primary PCI: insights from a cohort of 1391 patients European Heart Journal: Acute Cardiovascular Care 2013;2:1926.

13. Rao SV, O'Grady K, Pieper KS, et al. A comparison of the clinical impact of bleeding measured by two different classifications among patients with acute coronary syndromes. J Am Coll 
Cardiol 2006;47:809-16

14. White HD. The ATOLL trial of enoxaparin in primary percutaneous coronary intervention. Eur Heart J 2010;31:2826-7.

15. Giugliano RP, White JA, Bode C, et al. Early versus delayed, provisional eptifibatide in acute coronary syndromes. N Engl J Med 2009;360:2176-90.

16. Lardizabal JA, Joshi BK, Ambrose JA. The balance between antiischemic efficacy and bleeding risk of antithrombotic therapy in percutaneous coronary intervention: a Yin-Yang paradigm. J Invasive Cardiol 2010;22:284-92.

17. Alexander KP, Chen AY, Newby LK, et al. Sex differences in major bleeding with glycoprotein IIb/IIIa inhibitors: results from the CRUSADE (Can Rapid risk stratification of Unstable angina patients Suppress ADverse outcomes with Early implementation of the ACC/AHA guidelines) initiative. Circulation 2006;114:1380-7.

18. Mehran R, Pocock S, Nikolsky E, et al. Impact of bleeding on mortality after percutaneous coronary intervention results from a patient-level pooled analysis of the REPLACE-2 (randomized evaluation of PCI linking angiomax to reduced clinical events), ACUITY (acute catheterization and urgent intervention triage strategy), and HORIZONS-AMI (harmonizing outcomes with revascularization and stents in acute myocardial infarction) trials. JACC Cardiovasc Interv 2011;4:654-64. 